\title{
HYDRODYNAMIC INFLUENCE ON MEIOFAUNA DISTRIBUTION ON TWO SANDY BEACHES IN RIO DE JANEIRO
}

\author{
CATARINA RAMIS NOGUEIRA ${ }^{1, \dagger}$ \\ RODRIGO SOARES PEREIRA DE SKOWRONSKI ${ }^{1,2}$ \\ ${ }^{1}$ Departamento de Biologia Marinha - Universidade Federal \\ do Rio de Janeiro \\ ${ }^{2}$ Present Address: Instituto Oceanográfico - Universidade de \\ São Paulo - e-mail:rsko@ig.com.br) \\ ${ }^{\dagger}$ Deceased
}

\section{RESUMO}

A meiofauna de duas praias com diferentes características hidrodinâmicas no litoral do Rio de Janeiro foi estudada, uma em 1993 (SJB) e outra em 1994 (GB), com o objetivo de se fazer um levantamento inicial da comunidade para futuros trabalhos nestas áreas e de se entender melhor o papel que o hidrodinamismo possui na estruturação da comunidade meiofaunística. A praia de São José do Barreto (SJB), com $20 \mathrm{Km}$ de extensão, localiza-se no litoral norte e caracteriza-se pela alta energia das ondas. Por outro lado, a Praia do Galeão (GB), com 500 m de extensão, localiza-se no interior da Baía de Guanabara e possui características estuarinas. As amostras foram obtidas com um coletor de PVC de $30 \mathrm{~cm}$ de altura e 3,5 cm de diâmetro interno, subdividido em 2 segmentos de $15 \mathrm{~cm}$ de altura cada um. Foram realizados dez perfis em SJB e cinco em GB, com dois pontos de coleta em cada um dos mesmos. As análises sedimentológicas mostraram serem ambas as praias caracterizadas por areias grossas. Os grupos dominantes foram Nematoda, Oligochaeta, Turbellaria e Copepoda em ambas as praias. As densidades médias variaram de 14 a 390 ind.10 cm $\mathrm{cm} \mathrm{SJB} \mathrm{e}^{-2}$ de 241 a 989 ind.10 $\mathrm{cm}^{-2}$ na praia do Galeão. A Análise de Ordenação MDS demonstrou que a estrutura das comunidades da meiofauna foi direcionada principalmente pelas características granulométricas encontradas ao longo dos transectos e o hidrodinamismo parece estar influenciando diretamente o estabelecimento da meiofauna entre os estratos.

Palavras chave: Meiofauna, praias arenosas, distribuição espacial, hidrodinamismo, Rio de Janeiro.

\begin{abstract}
The meiofauna of two sandy beaches with different characteristics of the Rio de Janeiro State coast was studied. Surveys were undertaken in 1993 on the São José do Barreto beach (SJB) and in 1994 on the Galeão beach (GB). The aim of this study is to characterize the main meiofauna groups of these beaches and to understand how hydrodynamic forces may determine the meiofauna distribution. SJB is $20 \mathrm{~km}$ long and is characterized by high-energy waves. GB is a $500 \mathrm{~m}$ long sheltered beach located in the inner region of Guanabara Bay. Sediment samples were taken from ten transects on SJB and five on GB, each containing two stations, using a PVC core of $3.5 \mathrm{~cm}$ internal diameter and $30 \mathrm{~cm}$ long. The sediment was subdivided into two $15 \mathrm{~cm}$ segments and the organisms sorted under the stereomicroscope. Coarse sediments characterized both beaches and the meiofauna was dominated by nematodes, oligochaetes, turbellarians and copepods. Mean densities varied from 14 to 390 ind $10 \mathrm{~cm}^{-2}$ on SJB and from 241 to 989 ind $10 \mathrm{~cm}^{-2}$ on GB. MDS analysis demonstrated that differences in meiofauna distribution were strongly influenced by the
\end{abstract}


granulometric features along the transects and hydrodynamic forces directly determine the meiofauna vertical migration.

Key words: Meiofauna, sandy beaches, spatial distribution, hydrodynamics, Rio de Janeiro.

\section{INTRODUCTION}

Meiofauna organisms are the most abundant metazoans in marine sediments, characterized by a brief life cycle spent entirely within the sediment (Coull \& Giere, 1988). These organisms constitute an important link between micro- and macrofauna food chains, especially in estuaries and muddy sand beaches (Gee, 1989; Platt, 1989). Concerning these bioecological aspects, there has been an increase in the number of studies concerning the ecology of sandy beach meiofauna all over the world (Moore \& Bett, 1989).

In Brazil, although sandy beaches comprise nearly $80 \%$ of the exposed coastline, little is known about meiofauna distribution and the physical parameters that control its population structure (Medeiros, 1989 and 1992; Santos \& Fonsêca-Genevois, 1994).

Silva et al. (1986, 1991) studied the meiofauna distribution at Vermelha beach (RJ) and correlated the temporal distribution variation with wave energy. Several studies suggest that hydrodynamic forces influence macro and meiofauna population structure (Salvat, 1964; McLachlan, 1987).

In the present study the goals were: (1) to describe the main meiofauna taxa that occur on two sandy beaches in Rio de Janeiro and (2) to better understand how the hydrodynamic forces may determine the meiofauna distribution on two beaches with different wave intensities.

\section{STUDY AREAS}

The two beaches studied had different wave energy patterns and similar granulometric characteristics (Fig. 1).

São José do Barreto beach (SJB) $\left(22^{\circ} 20^{\prime} \mathrm{S} ; 41^{\circ} 40^{\prime} \mathrm{W}\right)$ is a $20 \mathrm{~km}$ long, reflective beach with a steep intertidal slope. There was a high frequency of waves, 2 waves impinging on the intertidal zone per minute with wave height attaining about $1.5 \mathrm{~m}$. Samples were collected in August 1993.

Galeão beach (GB) ( $22^{\circ} 50^{\prime} \mathrm{S}$; $\left.43^{\circ} 30^{\prime} \mathrm{W}\right)$ is a $500 \mathrm{~m}$ dissipative beach with a flat intertidal slope, located in Guanabara Bay. During the sampling period (January 1994) lower wave intensity in the sampling area $(<0.2 \mathrm{~m})$, and lower frequency of waves impinging on the intertidal zone were observed ( $<1$ wave/minute).

\section{MATERial AND Methods}

Transects were established $50 \mathrm{~m}$ apart perpendiculary to the tide line: 10 (A-J) on SJB beach and 5 (A-E) on GB. Two sampling stations were marked on each transect, one in the downward part of the swash zone (station I) and another $5 \mathrm{~m}$ upward (station II).

Samples were collected with PVC cores, $30 \mathrm{~cm}$ long of $3.5 \mathrm{~cm}$ internal diameter $\left(\sim 10 \mathrm{~cm}^{2}\right.$ in cross section) and divided into two $15 \mathrm{~cm}$ long sections (surface and deep stratum), labeled 1 and 2. They were preserved in $10 \%$ buffered formaldehyde and stained with Rose Bengal. At each station, 3 replicate core samples were taken. Sediment grain size was analyzed according to Suguio (1973). At each station, pore water temperature was measured using a mercury thermometer, and salinity using a refractometer. 
Organisms were sorted out from sand through flotation in a dense sugar solution. The solution was then filtered through a 500 and a $62 \mu \mathrm{m}$ mesh size sieve to separate macro- and meiofauna, respectively. This method was described by Anderson (1959) and standardized, for the present study, according to Esteves et al. (1995). This standardization allowed an extraction efficiency of over $95 \%$ of the total fauna.

A quantitative classification analysis was applied to investigate the taxa distribution patterns using the Bray-Curtis dissimilarity coefficient. The main taxa were clustered by the Weighted Pair Group Method Average (WPGMA) technique, after fourth root data transformation (Legendre \& Legendre, 1983). MDS (Multidimensional Scaling Analysis) was used to better understand the main factors determining the meiofaunal population structure on the beaches studied (Dillon \& Goldstein, 1984). This analysis was undertaken of the main taxa found on these beaches and with the abiotic sediment parameters mean diameter $(\phi)$, sorting coefficient $(\phi)$, skewness $(\phi)$, kurtosis $(\phi)$, temperature and salinity. The abiotic data were standardized to make descriptors compatible (Legendre \& Legendre, 1983). The Monte Carlo Test was performed to evaluate how effective the spatial distribution was and showed that the stations were not randomly spatially located in the ordination analysis (Sokal \& Rohlf, 1995). The paired-sample t-test was used to compare the densities of the main groups and the total meiofauna as between strata. An F-test was made before the $t$-test to assess the homocedasticity of the variances among the samples (Zar, 1996).

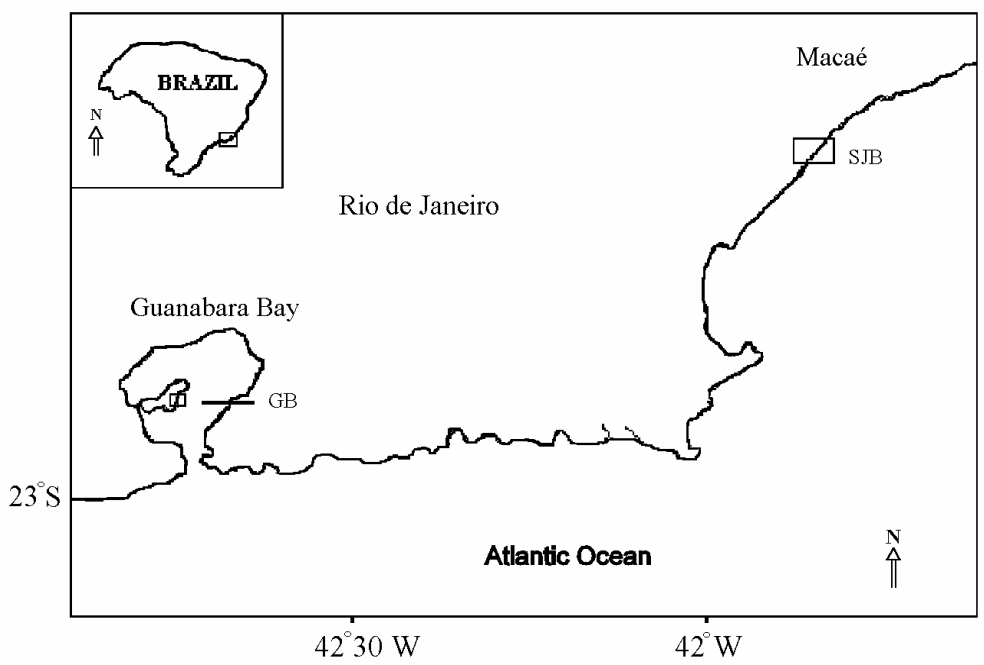

Figure.1 - Location of the two beaches studied. São José do Barreto (SJB) and Galeão (GB).

\section{RESULTS}

\section{São José do Barreto beach}

The granulometric analysis of SJB (Tab. 1) showed that the sediments are composed of coarse and very coarse sand. Mean diameter ranged from $-0.748 \phi(1.679 \mathrm{~mm})$ to $0.477 \phi(0.718$ $\mathrm{mm})$. Sorting coefficient ranged from 0.863 to $1.308 \phi$, being mainly poorly sorted, except for 
transects A, I and J, characterized as moderately sorted. For almost all the transects the sediment was characterized by positive skewness, exceptions being the transects $\mathrm{C}$ and I which presented more symmetrical sediment grains. Six transects presented sediment features characterized as leptokurtic, while transects $\mathrm{C}$ and $\mathrm{F}$ had platykurtic sediment features and the transects $\mathrm{E}$ and $\mathrm{J}$ mesokurtic.

Water and air temperature varied between 22 to $23^{\circ} \mathrm{C}$. The salinity value of around $35 \mathrm{~S}$ is characteristic of the exposed beaches in this area during winter months.

Table 1 - Environmental parameters of São José do Barreto beach - Rio de Janeiro - Brazil. Mean values for the two stations at each transect.

\begin{tabular}{|c|c|c|c|c|c|c|c|c|}
\hline \multirow{2}{*}{$\begin{array}{c}\text { Transect } \\
\text { SJB }\end{array}$} & \multicolumn{3}{|c|}{$\begin{array}{l}\text { Temp. } \\
\left({ }^{\circ} \mathrm{C}\right)\end{array}$} & \multirow{2}{*}{$\begin{array}{c}\text { Salinity } \\
\text { (S) }\end{array}$} & Mean diam. & Sort.coef. & \multirow{2}{*}{$\begin{array}{c}\text { Skewness } \\
(\phi)\end{array}$} & \multirow{2}{*}{$\begin{array}{c}\text { Kurtosis } \\
(\phi)\end{array}$} \\
\hline & air & water & sand & & \multicolumn{2}{|c|}{$(\phi)(\phi)$} & & \\
\hline A & 23 & 22 & - & 35 & - 0.608 & 0.991 & 0.187 & 1.241 \\
\hline B & 23 & 22 & - & 35 & - 0.748 & 1.165 & 0.475 & 1.21 \\
\hline $\mathrm{C}$ & 23 & 22 & - & 35 & 0.315 & 1.145 & 0.089 & 0.862 \\
\hline $\mathrm{D}$ & 23 & 22 & - & 35 & -0.229 & 1.178 & 0.277 & 1.15 \\
\hline $\mathrm{E}$ & 23 & 22 & - & 35 & 0.088 & 1.107 & 0.167 & 0.913 \\
\hline F & 24 & 23 & - & 35 & -0.070 & 1.157 & 0.165 & 0.889 \\
\hline G & 24 & 23 & - & 35 & -0.272 & 1.104 & 0.187 & 1.015 \\
\hline $\mathrm{H}$ & 24 & 23 & - & 35 & -0.193 & 1.308 & 0.36 & 1.453 \\
\hline I & 24 & 23 & - & 35 & 0.477 & 0.863 & 0.022 & 1.182 \\
\hline $\mathrm{J}$ & 24 & 23 & - & 35 & -0.044 & 0.958 & 0.121 & 0.993 \\
\hline
\end{tabular}

Meiofauna mean density ranged from 14 to 390 ind $10 \mathrm{~cm}^{-2}$ and was higher in transects $\mathrm{F}$ to J, mainly in the upper zone of the beach (Fig. 2). Densities varying from 14 to 250 ind $10 \mathrm{~cm}^{-2}$ were observed in the downward swash zone, and from 76 to 390 ind $10 \mathrm{~cm}^{-2}$ in the upward swash zone (Fig. 2).

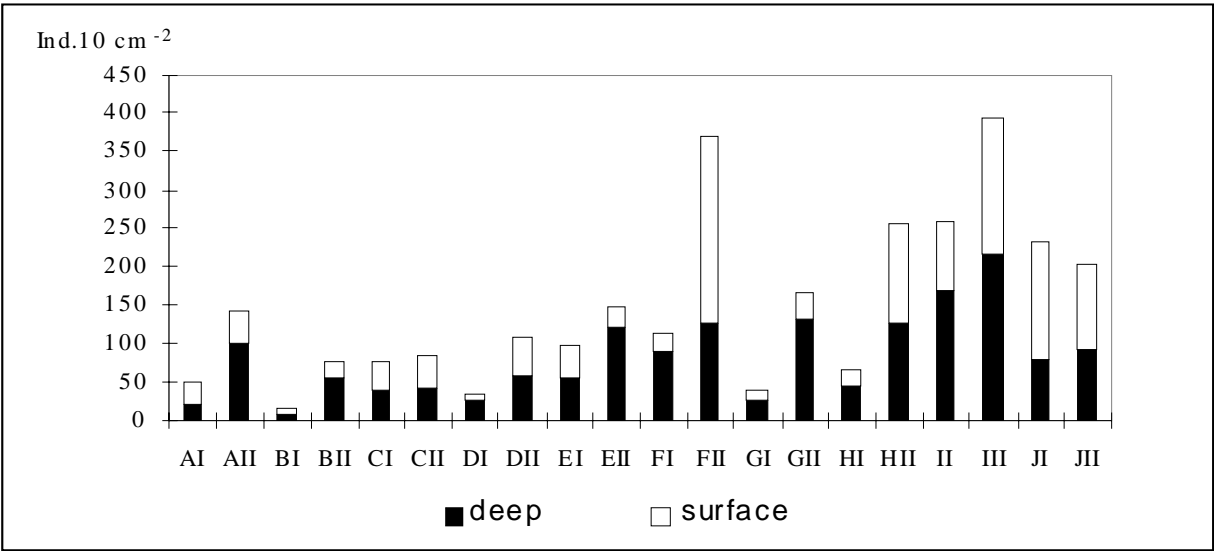

Figure2 - Mean density of meiofauna (ind.10 $\mathrm{cm}^{-2}$ ) on São José do Barreto beach. I downward swash zone; II - upward swash zone. 
When comparing the two strata, higher significant values were observed in the deep stratum for total meiofauna, nematodes and turbellarians (Tab.2).

Table 2 - Paired t-test between surface-deep strata samples of São José do Barreto beach. Critical Values: $\mathrm{DF}=29$

\begin{tabular}{llrcc}
\hline Taxon & Level & $\mathrm{t}-$ value & $\mathrm{p}$ & Results \\
\hline Nematoda & Station I & -20.603 & 0.0484 & Deep $>$ Surface \\
& Station II & -65.531 & $<0.001$ & Deep > Surface \\
Copepoda & Station I & -18.9655 & 0.0769 & N.S. \\
& Station II & -15.5340 & 0.0980 & N.S. \\
Turbellaria & Station I & -24.662 & 0.0198 & Deep $>$ Surface \\
& Station II & -25.153 & 0.0177 & Deep > Surface. \\
Oligochaeta & Station I & 0.7968 & 0.4324 & N.S. \\
& Station II & 17.965 & 0.0828 & N.S. \\
Meiofauna & Station I & -12.660 & 0.2156 & N.S. \\
& Station II & -21.642 & 0.0388 & Deep $>$ Surface \\
\hline
\end{tabular}

NS - not significant

I - downward swash zone

II - upward swash zone

Meiofauna consisted mainly of Nematoda (range: 1-104 with an average of 58 ind $10 \mathrm{~cm}^{-}$ ${ }^{2}$ ), comprising, in general, more than $65 \%$ of the total population sampled in the deep stratum at the upper stations of transects A to F. Nematoda densities were significantly higher in the deep stratum of both zones of the beach. Oligochaeta ranked as the second most numerous taxon (range: 2-120; average: 46 ind $10 \mathrm{~cm}^{-2}$ ), being more abundant mainly in the surface stratum and in the transects $\mathrm{H}$ and I, although differences in density between strata were not significant. Turbellaria (range: 1-54; average: 24 ind $10 \mathrm{~cm}^{-2}$ ) was well represented and attained about $40 \%$ of the total population numbers, mainly in the surface stratum at the downward stations of some transects. Turbellaria densities were always higher in the deep stratum. Copepoda (range:1-43; average: 13 ind $10 \mathrm{~cm}^{2}$ ) showed very irregular distribution at the sampling stations.

MDS analysis showed on the first axis a transect separation mainly caused by temperature. The samples located on the transects that had lower water temperatures (A to E) were separated from the samples located on the transects (F-J) which presented higher water temperatures. The second axis showed the importance of the granulometric features in the structuring of the meiofauna along the beach. It is interesting to note that the samples situated on the transects with finer sediments (I-J) were located far from the samples located at the transects that presented coarser, higher asymmetry and poorly sorted sediments (Fig. 3). The meiofauna density followed this pattern, where higher densities could be observed on the last five transects (F-J). The Monte Carlo test showed that the spatial separation among the samples was not random, since the stress for real data (7.9) was lower than the stress for randomized data with 30 runs (9.9). 


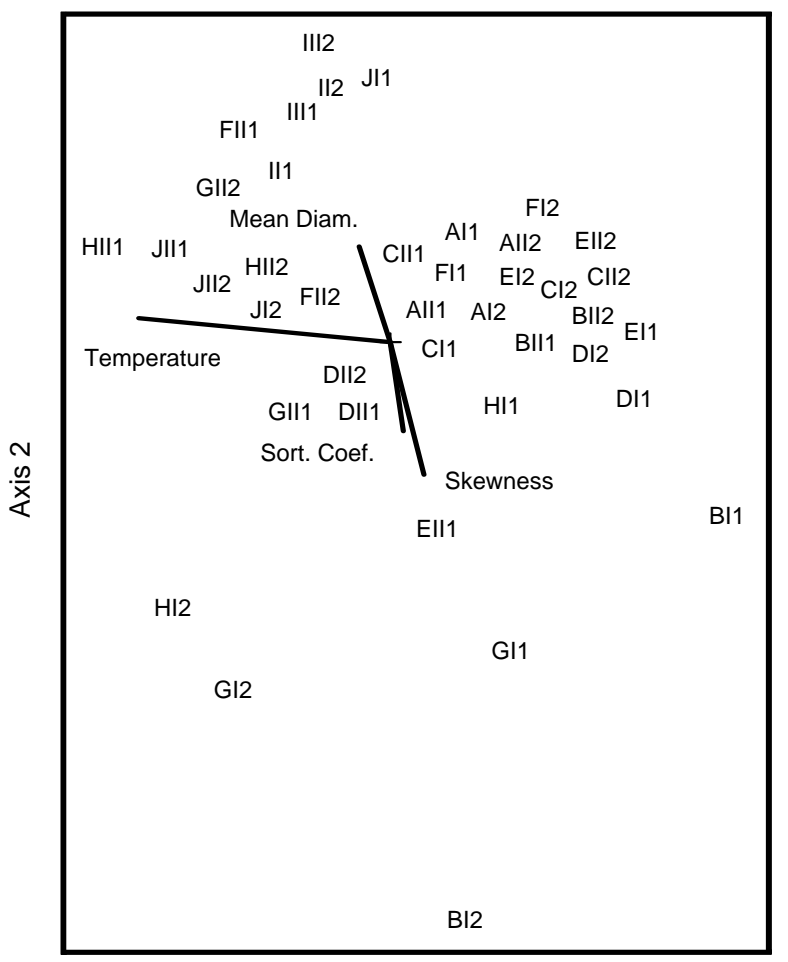

Axis 1

Figure 3 - MDS Analysis. São José do Barreto beach. A $\mathrm{J}$ - transects. I - swash zone; II - upper zone. 1 - surface stratum; 2 - deeper stratum. Relevant abiotic vectors are present.

\section{Galeão beach}

The mean diameter of the sediment on the Galeão beach ranged from - $0.654 \phi(1.573 \mathrm{~mm})$ to $0.471 \phi(0.721 \mathrm{~mm})$ characterizing it as a beach formed by coarse and very coarse sands. The sorting coefficient varied from 0.964 to 0.709 , the sand being moderately sorted. The sediment features of transects had symmetric distribution, except for the last transect, E, that had asymmetric positive distribution. The kurtosis distribution showed a gradient, whereas on the first two transects (A and $\mathrm{B}$ ) the sediment was characterized by leptokurtic distribution, on transects $\mathrm{C}$ and $\mathrm{E}$ the sediment was characterized by platykurtic distribution and on transect D showed mesokurtic distribution (Tab. 3).

Air, water and sediment temperature varied from 25 to $34^{\circ} \mathrm{C}$. Sediments usually showed lower temperatures than the water. In summer months, salinity was $24 \mathrm{~S}$, characteristic of typical estuarine bay waters (Tab. 3). 
Table 3 - Environmental parameters of Galeão beach - Rio de Janeiro - Brazil.

\begin{tabular}{cccccrrrrr}
\hline Transect & \multicolumn{3}{c}{ Temp. $\left({ }^{\circ} \mathrm{C}\right)$} & \multicolumn{3}{c}{ Salinity } & \multicolumn{3}{c}{ Mean diam. Sort.coef. Skewness } \\
\hline GB & Air & water & sand & \multicolumn{1}{c}{$(\mathrm{S})$} & $(\phi)$ & $(\phi)$ & \multicolumn{1}{c}{$(\phi)$} & $(\phi)$ \\
\hline A & 25 & 27 & 28 & 24 & 0.169 & 0.964 & -0.111 & 1.513 \\
B & 32 & 31 & 28 & 24 & 0.471 & 0.709 & -0.090 & 2.095 \\
C & 30 & 31 & 29 & 24 & -0.654 & 0.825 & -0.054 & 1.137 \\
D & 34 & 31 & 30 & 24 & -0.107 & 0.866 & 0.07 & 1.05 \\
E & 34 & 32 & 30 & 24 & -0.097 & 0.952 & 0.109 & 1.155 \\
\hline
\end{tabular}

Mean meiofauna density ranged from 241 to 989 ind $10 \mathrm{~cm}^{-2}$ and was higher on transects C to E, mainly in the swash zone of the beach (Fig. 4). Among sampling stations, maximum abundance occurred at the swash zone stations, mainly on the last three transects. Meiofauna numbers from 297 to 989 ind $10 \mathrm{~cm}^{-2}$ were observed in the swash zone, and from 241 to 605 ind.10 $\mathrm{cm}^{-2}$ in the upper zone (Fig. 4).

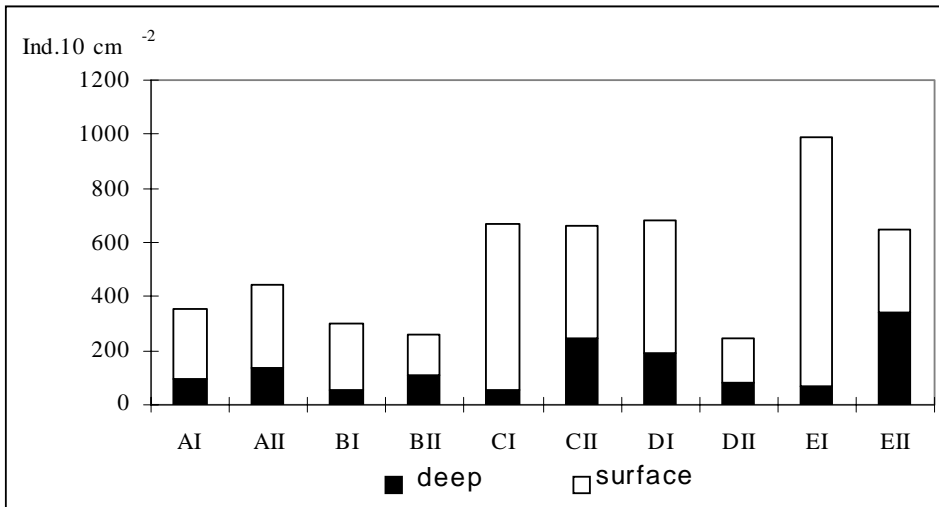

Figure 4 - Mean density of meiofauna (ind.10 $\mathrm{cm}^{-2}$ ) on Galeão beach.. I downward swash zone; II - upward swash zone.

The comparison of total meiofauna from the two strata showed that, at both stations, differences in density were significant, generally being higher in the surface stratum (Tab. 4).

Table 4 - Paired t-test between surface-deep strata samples from Galeão beach. Critical values: $\mathrm{DF}=14$

\begin{tabular}{lllrc}
\hline Taxon & Level & $\mathrm{t}-$ value & $\mathrm{p}$ & Results \\
\hline Nematoda & Station I & 51.925 & 0.0001 & Surface $>$ Deep \\
& Station II & 24.425 & 0.0285 & Surface $>$ Deep \\
Oligochaeta & Station I & 37.187 & 0.0023 & Surface $>$ Deep \\
& Station II & 0.9969 & 0.3357 & N. S. \\
Copepoda & Station I & 29.988 & 0.0096 & Surface $>$ Deep \\
& Station II & 19.101 & 0.0768 & N. S. \\
Meiofauna & Station I & 81.292 & $<0.0001$ & Surface $>$ Deep \\
& Station II & 23.857 & 0.0317 & Surface $>$ Deep \\
\hline
\end{tabular}

N.S. - not significant; I - downward swash zone; II - upward swash zone 
Considering the relative importance of the organisms sampled, the most abundant taxon were the Oligochaeta (range: 8-400; average: 213 ind $10 \mathrm{~cm}^{-2}$ ), which represented more than 40\% of the total fauna in most samples of both strata. Nematoda (range: 4-157; average: 106 ind $10 \mathrm{~cm}^{-2}$ ) had a very regular distribution at all the sampling stations, representing between 7 and $37 \%$ of the total meiofauna. Copepoda ranked as the third most abundant group on GB (range: 2-126; average: 55 ind $10 \mathrm{~cm}^{-2}$ ), corresponding to $2-32 \%$ of the total population. Turbellaria (range: $1-77$; average: 38 ind $10 \mathrm{~cm}^{-2}$ ) showed relative frequencies ranging from 1 to $28 \%$, with a reduction on the last two transects. Polychaets were very abundant in the surface samples (range: 0-433; average: 105 ind 10 $\mathrm{cm}^{-2}$ ) of $\mathrm{C}$ to E transects; however, this group was virtually absent from the bottom samples.

MDS results, with the main taxa (Nematoda, Copepoda and Oligochaeta) on the first axis, showed a tendency to separate the samples located in the upward and downward swash zones. On the second axis, it was possible to observe the granulometric features contributing to the meiofauna distribution. The samples located on the transects represented by coarser sediments were separated from the samples located at the first two transects (A and B) which were characterized by finer grains and leptokurtic distribution. (Fig. 5). The Monte Carlo test showed that the spatial separation among the samples was not random, since the stress for real data (6.3) was lower than the stress for randomized data with 30 runs (6.9).

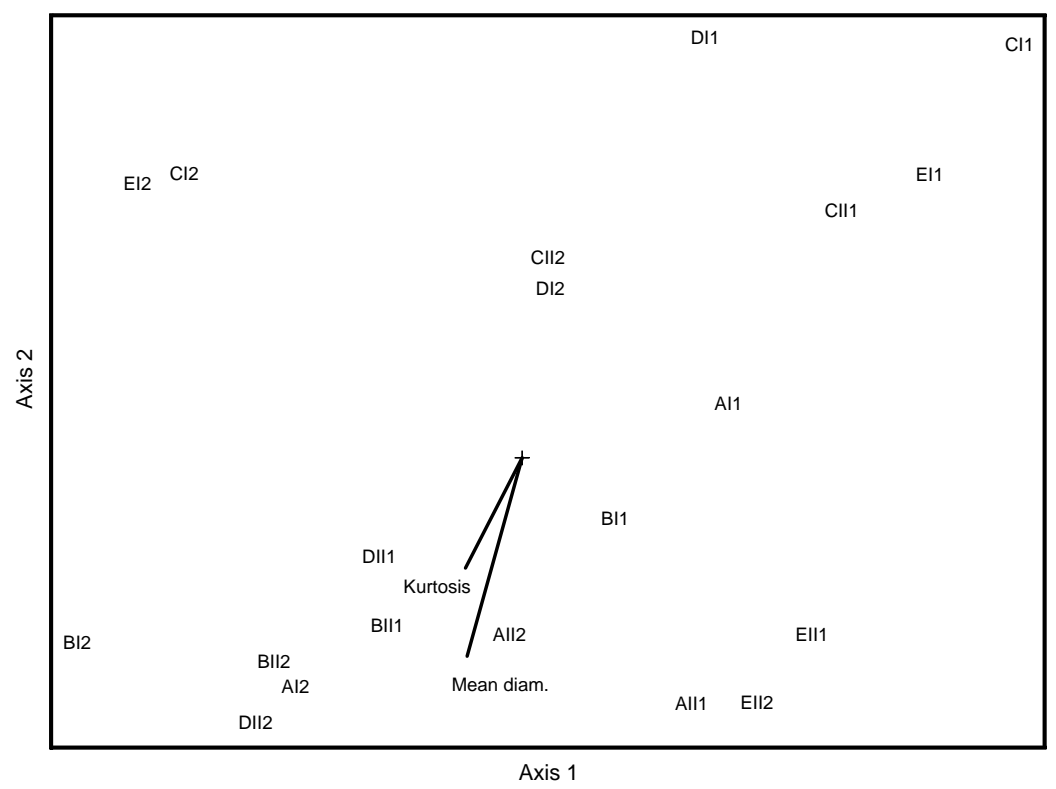

Figure 5 - MDS Analysis. Galeaõ beach. A - E - transects. I - swash zone; II - upper zone. 1 - surface stratum; 2 - deeper stratum. Relevant abiotic vectors are present.

\section{DISCUSSION}

The distribution of organisms on sandy beaches is subject to the influence of complex agents, such as wave action, beach slope, particle diameter, porosity and humidity (Hulings \& Gray, 1971; Mclachlan, 1983). Grain size is in many cases the most important agent to determine spatial and structural conditions for meiofauna establishment (Gray, 1974; McLachlan \& Turner, 1994). 
Our study demonstrates the importance of grain size as determining the meiofauna diversity, so although there were hydrodynamic differences between the two beaches, the main taxa constituting the meiofauna population were similar: Nematoda, Copepoda, Turbellaria and Oligochaeta. In coarser sands, these groups usually predominate (Swedmark, 1964) and in finer grains the diversity is generally higher (Gray \& Rieger, 1971). The dominant meiofauna taxon is usually Nematoda, even in coarser sand, where it can be found up to $1 \mathrm{~m}$ deep in the sediment (Fenchel \& Riedl, 1970). These organisms may be replaced by the Oligochaeta on some beaches, as observed by Jansson (1968) on some Swedish beaches. The prevalence of specialized nematodes and oligochaetes it was also observed in dry sand, characterized by low water saturation (Giere, 1993).

On SJB, the Oligochaeta occurred in similar numbers in both strata, however the Copepoda was poorly represented in the samples. Probably, due to a deeper meiofauna distribution in the area and/or to the inadequate sampling depth which influenced the results obtained for the organisms' vertical distribution on this beach. The oligochaetes dominance on GB might be linked to the estuarine conditions of the sampling area. Oligochaetes usually tolerate wider ranges of environmental factors (Armonies \& Hellwig-Armonies, 1987), which might explain the dominance of that group on the GB beach.

Besides the differences in densities found on the two beaches studied, meiofauna densities in general were low, in agreement with McLachlan's (1987) study, according to which meiofauna population density was generally low with a tendency to increase in finer sediments. Furthermore, McIntyre \& Murison (1973) demonstrated that the optimum grain size for meiofauna distribution on beaches was $230 \mu \mathrm{m}$ and, on the two beaches here studied, the grain size was often larger than 500 $\mu \mathrm{m}$, which might restrained the meiofauna settlement.

It is important to note that the organisms' spatial distribution along the beaches evidenced the strong influence of the granulometric features of the transects. For example, higher organism densities were found on the transects with finer grain sizes. Furthermore, other sediment features like sorting coefficient, skewness and kurtosis contributed to the spatial distribution of the meiofauna along the transects. The MDS analysis showed the importance of these factors on meiofauna distribution. Bally (1983) and Zanata (1990) have already demonstrated the importance of skewness and kurtosis in determining the distribution of meiofauna organisms on sandy beaches. On SJB, higher meiofauna densities were observed at transects located on sediments characterized by better sorted grains with higher symmetry. On GB, kurtosis played an important role in meiofauna distribution, where the sediments that presented leptokurtic distribution had fewer meiofauna organisms.

Physical parameters beyond granulometry are also important to meiofauna ecology. For instance, temperature may contribute to restrain meiofauna colonization as shown by Jansson (1967). During the sampling on SJB and GB, probably due to the action of the sun, an increase in water temperature was observed. A higher density of meiofauna organisms was observed on the transects affected by higher water temperatures. This was also true of GB, although MDS analysis did not demonstrate it. However, these differences found in the meiofauna community among the transects in a more highly dynamic habitat might be linked to other sedimentary features, such as mean diameter, sorting coefficient, impact of the waves and beach slope. In fact, temperature appears to be a secondary parameter, for example: the transects on SJB that had higher water temperatures and meiofauna densities, were also those which presented a finer mean grain diameter, which suggests that the temperature was not alone responsible for the spatial distribution of the meiofauna community.

The meiofauna vertical distribution varied between the two beaches. The aim of this study was not to compare the two beaches, but to compare how the hydrodynamic forces influence the meiofauna distribution on sandy beaches. No reducing layer was observed on SJB, suggesting a 
deeper distribution of meiofauna than that seen in the $30 \mathrm{~cm}$ column of the samples. The impact of the waves on the stations might the meiofaunal population downwards into the deep stratum, where conditions were more suitable for life. These layers are better protected from the water flux and, consequently, from sediment disturbance. McLachlan (1990) has already recognized the influence of wave action on meiofauna response, as it attempts to escape in downward migration to more suitable conditions.

Although GB has coarse and moderately sorted sediments, very similar to SJB beach, it is situated in a sheltered area. The higher meiofauna density of this beach is probably to be associated with the reduced wave exposure or other parameters, such as organic matter, sediment content and microphytobenthic biomass that have not been analyzed in this study. It is known that the meiofauna is related to these parameters, as potential available food (Santos et al., 1995; Miller et al., 1996) and in estuarine habitats there are usually higher concentration of organic matter and microphytobenthic biomass in the sediment. Comparing densities between the strata, higher values were observed in the surface stratum, that could be related to the reduced layer detected near the surface. In sheltered places there is a typical reduction layer in close proximity to the surface sediment, where only specialized organisms are able to survive (Fenchel \& Riedl, 1970).

The differences found among the stations were not so clear, it seems that besides the variation in the hydrodynamics associated with the two beaches and the consequent beach characteristics, the stations presented no great differences whether as regards the sediment parameters or the meiofauna community. The beach slope and the distance between the stations give the impression that this distance, even on the SJB beach, was not large enough to lead to significant differences between the stations. Probably, if the distance between the stations were greater, differences between the sediments and the communities would be found.

Although accurate comparisons with the literature are difficult due to the different methods used, the present results agree with data reported for tropical beaches with similar grain sizes (Bush, 1966; McLachlan, 1977; Sarma \& Mahan, 1981 Dye, Mclachlan \& Wooldridge, 1981; Mclachlan, Wooldridge \& Dye, 1981).

\section{CONCLUSiONS}

The results presented in this study, based on high taxonomic levels, evidenced a general distribution of the meiofauna and its dominant taxa similar to those observed on other sandy beaches around the world. It was possible to observe some environmental factors determining the meiofauna population of the sandy beaches studied. The granulometric features were very important for meiofauna distribution along the transects, in terms of both diversity and density. Furthermore, it was possible to identify a hydrodynamic influence on vertical settlement of meiofauna.

\section{REFERENCES}

ANDERSON, R. O.A modified flotation technique for sorting bottom fauna samples. Limnol. Oceanogr., v. 4, p. 223-225, 1959.

ANSARI, Z. A.; INGOLE, B. S. Meiofauna of some sandy beaches of Andaman Islands. Indian J. Mar. Scien., v. 12, p. 245-246, 1983.

ARMONIES, W.; HELLWIG-ARMONIES, M. Synoptic patterns of meiofaunal and macrofaunal abundances and specific composition in littoral sediments. Helgoländer Meeresunters, v. 41, p. 83-111. 1987. 
BALLY, R. Sandy beaches ecology. Factors affecting the distribution of organisms in the intertidal zones of sandy beaches. In: McLACHLAN, A.; ERASMUS, T. (Ed.), The Hague, W. Junk. Publishers, Boston/Lancaster. 1983. 757p.

BUSH, L. F. Distribution of sand fauna in beaches at Miami, Florida. Bull. Mar. Sci., v. 16, p. 5875, 1966.

COULL, B. C.; GIERE, O. The History of Meiofaunal Research. In: HIGGINS; R. P.; THIEL, H. (Ed). Introduction to the Study of Meiofauna. Smithson. Instit. Press, Washington D.C, 1988, p.196-235.

DILLON, W. R.; GOLDSTEIN, M. Multivariate Analysis. In: DILLON. W.R.; GOLDSTEIN, M. (Ed). Methods and Applications. John Wiley \& Sons, New York, 1984, 585p.

DYE, A.H., MCLACHLAN, A.; WOOLDRIDGE, T. The ecology of sandy beaches in Natal. S. Afr. J. Zool., v. 16, p. 200-209, 1981.

ESTEVES, A. M.; ABSALÃO, R. S.; da SILVA, V. M. A.. P. Padronização e avaliação da eficiência do método da flotação na extração da meiofauna em uma praia de areia grossa (Praia Vermelha, RJ). Publicação Esp. Inst. oceanogr. S Paulo, v. 11, p. 223-227, 1995.

FENCHEL, T. M.; RIEDL, R. J. The sulfide system: A new biotic community under the oxidized layer of marine sand bottoms. Mar. Biol., v. 7, p. 255-268, 1970.

GEE, J. M. An ecological and economic review of meiofauna as food for fish. Zool. J. Linnean Soc., v. 96, p. 243-261, 1989.

GIERE, O. Meiobenthology: the microscopic fauna in aquatic sediments. Springer-Verlag, Berlin, 1993, 328 pp.

GRAY, J. Animal-sediment relationships. Oceanogr. mar. Biol. a. Rev., v. 12, p. 223-261. HULINGS, N. C.; GRAY, J. S. A manual for the study of meiofauna. Smithsonian Contrib. Zool., v. 78, p. 1-84, 1971.

JANSSON, B.O. The significance of grain size and pore water content for the interstitial fauna of sandy beaches. Oikos, v. 18, p. 311-322, 1969.

JANSSON, B.O. Quantitative and experimental studies of the interstitial fauna in four Swedish sandy beaches. Ophelia, v. 5, p. 1-71, 1968.

LEGENDRE, L.; LEGENDRE, P. Numerical Ecology. Elsevier, New York, USA. 1983.

McINTYRE, A. D. Ecology of marine meiobenthos. Biol. Rev., v. 44, p. 245-290. 1969.

McLACHLAN, A. Composition, distribution, abundance and mass of the macro and meiofauna of four sandy beaches. Zool. Africana, v. 12, p. 279-306, 1977. 
McLACHLAN, A., WOOLDRIDGE, T.; DYE, A. H. The ecology of sandy beaches in southern Africa. S.-Afr. Tydskr. Dierk., v. 16, p. 219-231, 1961.

McLACHLAN, A. Sandy beaches ecology-A review. Sandy beaches as ecosystem. In: McLACHLAN, A.; ERASMUS, T.(Ed.), The Hague, W. Junk. Publishers. 1983, p. 321 -380.

McLACHLAN, A. Behavioural adaptations of sandy beach organisms: an ecological perspective. In: CHELAZZI. G.; VANINI, M. (Eds.). Behavioural adaptation to intertidal life. Plenum Press, New York. 1987. p. 449-475.

McLACHLAN, A. Interstitial ecology. In: BROWN, A. C.; McLACHLAN, A. (Eds.). Ecology of sand shores Elsevier, Amsterdam. 1990, p. 145-163.

McLACHLAN, A.; TURNER, I. The interstitial environment of sandy beaches. Mar. Ecol. PSZNI, v. 15, p. 177-211, 1994.

MEDEIROS, L. R. de A. Meiofauna de Praia Arenosa da Ilha Anchieta, 1989, 388f. São Paulo. Dissertação de Mestrado. Universidade de São Paulo, Instituto de Biociências.

MEDEIROS, L. R. de A. Meiofauna da praia arenosa da Ilha Anchieta, São Paulo: I.Fatores físicos. Bolm Inst. oceanogr., S. Paulo, v. 40, p. 27-38, 1992.

MILLER, D. C.; GEIDER, R. J.; MacINTYRE, H. L. Microphytobenthos: The ecological role of the "secret garden" of unvegetated, shallow-water marine habitats. II. Role in sediment stability and shallow-water food-webs. Estuaries, v. 19, p. 202-212, 1996.

MOORE, C. G.; BETT, B. J. The use of meiofauna in marine pollution impact assessment, Zool. J. Linnean Soc., v. 96, p. 263-280, 1989.

PLATT, H. M. Meiofauna: recent advances and economic assessment. Zool. J. Linnean Soc., v. 96, p. 213-216, 1989.

SALVAT, B. Les conditions hydrodynamiques interstitielles des sédiments meubles intertidaux et la répartition verticale de la fauna endogée. Acad. Sci. Paris, v. 259: 1576-1579, 1964.

SANTOS, P. M. L.; FONSÊCA-GENEVOIS, V. Meiofauna como vetor de impacto ambiental na Baía de Suape-PE: Densidade e estimativa do índice Nematoda/Copepoda. Rev. Nord. Zool., v. 1: 15-19, 1994.

SANTOS, P. J. P.; CASTEL, J.; SOUZA-SANTOS, L. P. Microphytobenthic patches and their influence on meiofaunal distribution. Cah. Biol. Mar., v. 36, p. 133-139, 1995.

SARMA, N. S. R.; MAHAN, P. C. On the ecology of the interstitial fauna inhabiting the Bhimilipatnam coast (Bay of Bengal). Mahasagar, v. 14, p. 257-263, 1981.

SILVA, V. M. A. P.; GROHMANN, P. A.; NOGUEIRA, C. S. R. Contribuição ao estudo das comunidades animais do sustrato móvel marinho: In: MEIOFAUNA DA PRAIA VERMELHA, R.J. RESUMOS DO XIII CONGRESSO BRASILEIRO DE ZOOLOGIA, 4. 1986, p. 257. 
SILVA, V. M. A. P.; GROHMANN, P. A.; NOGUEIRA, C. S. R. Studies on meiofauna on Rio de Janeiro coast, Brazil. Costal Zone, v. 564, p. 1-13, 1991.

SOKAL, R.; ROHLF, F. J., Biometry. ${ }^{\text {rd }}$, W.H. Freeman and Company, New York. 1995. 896p.

SUGUIO, K. Introdução à Sedimentologia. Edgard Blucher, São Paulo. 1973, 317p.

SWEDMARK, B. The interstitial fauna of marine sand, Biol. Rev., v. 39, p. 1-42, 1964.

ZANATA, A.S. Distribuição espaço-temporal de uma espécie do gênero Macrochaeta Grube, 1851 (Polychaeta: Acrocirripdae) na praia Vermelha - RJ. Rio de Janiero. 1990, 92f. Monografia (Graduação) - Universidade Federal do Rio de Janeiro, Departamento de Biologia Marinha.

ZAR, J. H. Biostatistical Analysis. ${ }^{\text {rd }}$, Englewood Cliffs, Prentice-Hall, New Jersey. 1996, 662p. 
Tropical Oceanography, Recife: v. 31, n. 2, 2003. 